Article

\title{
Three Novel Triterpenoids from Taraxacum officinale Roots
}

\author{
Takashi Kikuchi, Ayaka Tanaka, Mayu Uriuda, Takeshi Yamada and Reiko Tanaka * \\ Laboratory of Medicinal Chemistry, Osaka University of Pharmaceutical Sciences, 4-20-1 Nasahara, Takatsuki, \\ Osaka 569-1094, Japan; t.kikuchi@gly.oups.ac.jp (T.K.); e11531@gap.oups.ac.jp (A.T.); \\ cocoon.020217@gmail.com (M.U.); yamada@gly.oups.ac.jp (T.Y.) \\ * Correspondence: tanakar@gly.oups.ac.jp; Tel./Fax: +81-726-901-084
}

Academic Editors: Vassilios Roussis and Efstathia Ioannou

Received: 25 July 2016; Accepted: 20 August 2016; Published: 27 August 2016

\begin{abstract}
Three novel lupane-, bauerane-, and euphane-type triterpenoids (1-3), in addition

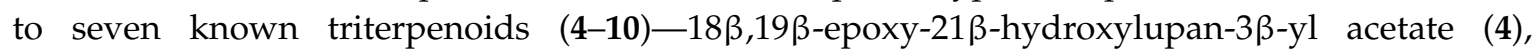
21-oxolup-18-en-3 $\beta$-yl acetate (5), betulin (6), officinatrione (7), $11 \alpha$-methoxyolean-12-en-3-one (8), eupha-7,24-dien-3-one (9), and 24-oxoeupha-7,24-dien-3 $\beta$-yl acetate (10)—were isolated from the roots of Taraxacum officinale. Their structures were elucidated on the basis of spectroscopic analyses using 1D and 2D-NMR spectra and electron ionization mass spectrometry (EIMS). The effects of compounds 1-10 on the production of nitric oxide (NO) in lipopolysaccharide (LPS)-activated mouse peritoneal macrophages were evaluated. Compounds 4, 6, and 10 exhibited similar NO inhibitory activities to $\mathrm{N}^{\mathrm{G}}$-monomethyl-L-arginine acetate (L-NMMA). These compounds did not exhibit cytotoxicity at an effective concentration. The results of present study suggest that compounds 4, 6, and 10 have potential as anti-inflammatory disease agents.
\end{abstract}

Keywords: $\quad 18 \beta, 19 \beta$-epoxy-21 $\beta$-methoxylupan-3 $\beta$-yl acetate; $3 \beta$-acetoxybauer-7-en-6-one; $3 \beta$-acetoxyeuph-7,24-dien-6-one; Taraxacum officinale; dandelion; triterpene; NO production

\section{Introduction}

Taraxacum officinale (commonly known as dandelion) has a number of culinary and medicinal uses, despite being generally regarded as a weed. Dandelion is the general name of approximately two thousand species of plants that belong to the genus Taraxacum (Compositae). Young leaves and inflorescences are used as ingredients in salads and stir-fries. Dandelion roots have long been largely used on the continent, and the plant is cultivated largely in India as a remedy for liver complaints. Dandelion roots contain bitter principles that have a tonic effect on the liver and digestive system [1]. It is also a gentle laxative and natural diuretic that is rich in natural potassium, which enriches the body's supply. It has been used as a tonic to treat rheumatic issues and also acts as a blood purifier [2]. In recent studies, it was revealed that dandelion extract may play a significant role during adipogenesis and lipid metabolism, and may have the potential for the treatment of obesity [3]. Dandelion is available as capsules, liquid extracts, and tea forms [4]. We previously reported five novel lupan-type triterpenoids isolated from the roots of $T$. officinale. Of these, officinatrione, a (17S)-17,18-seco-lupane was identified as a new carbon skeletal triterpenoid [5]. We herein reported three new triterpenoids: $18 \beta, 19 \beta$-epoxy-21 $\beta$-methoxylupan-3 $\beta$-yl acetate (1), $3 \beta$-acetoxybauer-7-en-6-one (2), 3 $\beta$-acetoxyeupha-7,24-dien-6-one (3), in addition to seven known compounds (4-10) (Figure 1). The isolated compounds (1-10) were evaluated for their inhibitory activities on macrophage activation using an inhibitory assay of nitric oxide (NO) production in RAW 264.7 mouse macrophages stimulated by lipopolysaccharide (LPS). 


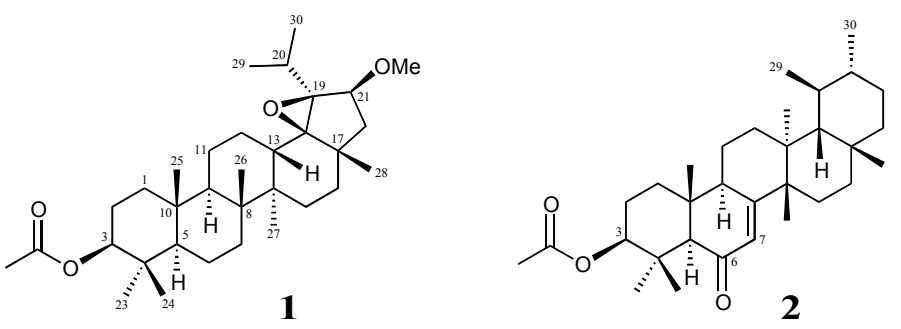

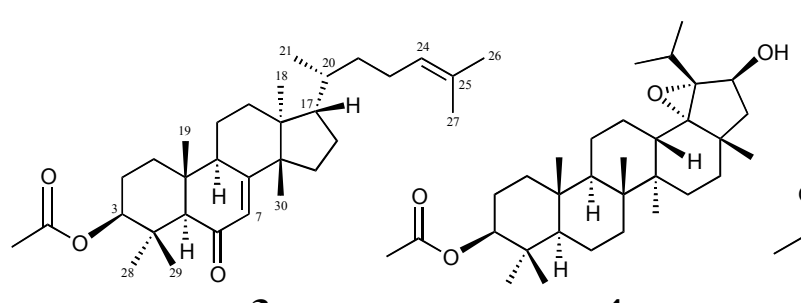

3

4

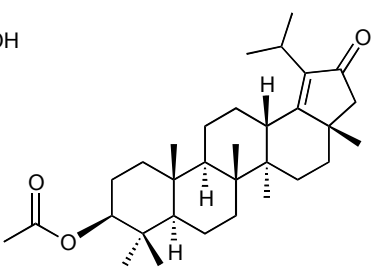

5<smiles>C=C(C)C1CCC2(CO)CCC3C(CCC4C3CCC3(C)C(C)C(O)CCC43C)C12</smiles>

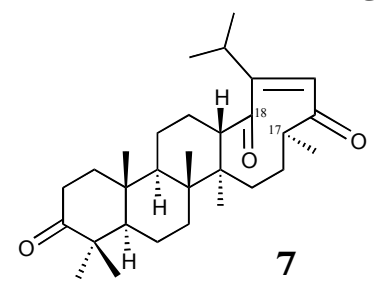

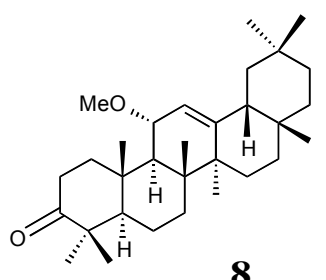

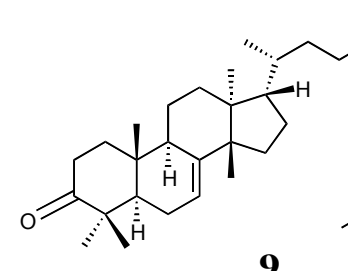

9

10

Figure 1. Chemical structures for compounds 1-10.

\section{Results and Discussion}

The methanol extract of the roots of T. officinale $(5.81 \mathrm{~kg})$ was partitioned between EtOAc and water. The organic layer was condensed in vacuo to give a yellowish residue ( $890 \mathrm{~g})$ and separated by silica gel chromatography followed by HPLC [octadecyl silica (ODS), $\mathrm{MeOH}-\mathrm{H}_{2} \mathrm{O}$ (95:5)] to afford the novel lupane, bauerane, euphane-type triterpenes, as well as seven known triterpenes.

Compound 1 was obtained as colorless needles, the molecular ion peak at $\mathrm{m} / z 514.4022$ in high resolution (HR) electron ionization (EIMS) of which showed the molecular formula $\mathrm{C}_{33} \mathrm{H}_{54} \mathrm{O}_{4}$ (calcd. for 514.4022). Its IR spectrum showed the presence of an ester group at 1739 and $1246 \mathrm{~cm}^{-1}$. Detailed assignments of ${ }^{1} \mathrm{H}$ - and ${ }^{13} \mathrm{C}-\mathrm{NMR}$ spectra (Table 1) using hetero-nuclear single quantum coherence (HSQC) and distorsionless enhancement by polarization transfer (DEPT) methods revealed the presence of six tertiary methyls $\left(\delta_{\mathrm{H}} 0.84,0.85,0.88,1.05,1.075\right.$ and 1.083 (each $\left.3 \mathrm{H}, \mathrm{s}\right)$ ), two secondary methyls $\left(\delta_{\mathrm{H}} 1.11(6 \mathrm{H}, \mathrm{d}, J=7.4 \mathrm{~Hz})\right)$, an acetyl methyl $\left(\delta_{\mathrm{H}} 2.04(\mathrm{~s}), \delta_{\mathrm{C}} 171.0(\mathrm{~s})\right)$, nine methylenes, six methines including two oxymethines $\left(\delta_{\mathrm{H}} 3.77(\mathrm{~d}, J=5.9 \mathrm{~Hz}), \delta_{\mathrm{C}} 83.2(\mathrm{~d}) ; \delta_{\mathrm{H}} 4.47(\mathrm{dd}, J=11.4,5.3 \mathrm{~Hz})\right.$, $\delta_{\mathrm{C}} 80.9(\mathrm{~d})$ ), five quarternary carbons, and two oxygenated sp ${ }^{3}$ quaternary carbons $\left(\delta_{\mathrm{C}} 71.9(\mathrm{~s}), 77.0(\mathrm{~s})\right)$. EIMS showed fragment ion peaks characteristic of the cleavage of the C-ring at $m / z 249\left(\mathrm{C}_{16} \mathrm{H}_{25} \mathrm{O}_{2}\right)$ and 189 (249- HOAc), which revealed the presence of an acetyl group at the C-3 position [6]. The planar structure of 1 was established using the hetero-nuclear multiple quantum coherence (HMBC) spectrum, and selected $\mathrm{HMBC}$ correlations are shown in Figure 2. Strong correlations were observed between Me-23, $24\left(\delta_{\mathrm{H}} 0.85,0.84\right.$, respectively) and C-3 $\left(\delta_{\mathrm{C}} 80.9\right), \mathrm{C}-4$, and C-5; between Me-25 $\left(\delta_{\mathrm{H}} 0.88\right)$ and C-1, C-5, C-9, and C-10; between Me-26 $\left(\delta_{\mathrm{H}} 1.075\right)$ and C-7, C-8, C-9, and C-14; between Me-27 $\left(\delta_{\mathrm{H}} 1.05\right)$ 
and C-8, C-13, C-14, and C-15; between Me-28 $\left(\delta_{\mathrm{H}} 1.083\right)$ and C-16, C-17, C-18 $\left(\delta_{\mathrm{C}} 77.0\right)$, and C-22; between Me-29, $30\left(\delta_{\mathrm{H}} 1.11(6 \mathrm{H})\right)$ and C-19 $\left(\delta_{\mathrm{C}} 71.9\right)$, and C-20 $\left(\delta_{\mathrm{C}} 29.4\right)$; between H-13 $\left(\delta_{\mathrm{H}} 2.48\right)$ and C-11, C-12, C-14, C-15, C-17, C-18, C-19, and C-27; between H-21 ( $\left.\delta_{\mathrm{H}} 3.77\right)$ and C-17, C-18, C-19, $\mathrm{C}-20$, and $\mathrm{C}-22$; and between OMe $\left(\delta_{\mathrm{H}} 3.22\right)$ and $\mathrm{C}-21$. In the ${ }^{1} \mathrm{H}-{ }^{1} \mathrm{H}$ correlation spectroscopy (COSY) spectrum, cross peaks were observed between $\mathrm{H}-21\left(\delta_{\mathrm{H}} 3.77\right)$ and $\mathrm{H}_{2}-22\left(\delta_{\mathrm{H}} 1.18,1.32\right)$ and also between $\mathrm{H}-3$ and $\mathrm{H}_{2}-2\left(\delta_{\mathrm{H}} 1.64(2 \mathrm{H})\right)$, and other cross peaks are shown by bold-faced lines in Figure 2. The relative configuration was established by the nuclear overhauser effect correlated spectroscopy (NOESY) spectrum (Figure 2); between $\mathrm{H}-3 \alpha\left(\delta_{\mathrm{H}} 4.47\right)$ and $\mathrm{H}-5 \alpha\left(\delta_{\mathrm{H}} 0.81\right)$ and Me-23 $\left(\delta_{\mathrm{H}} 0.85\right)$; between $\mathrm{H}-5 \alpha\left(\delta_{\mathrm{H}} 0.81\right)$ and $\mathrm{H}-9 \alpha\left(\delta_{\mathrm{H}} 1.38\right)$; between Me-24 $\left(\delta_{\mathrm{H}} 0.84\right)$ and Me-25 $\left(\delta_{\mathrm{H}} 0.88\right)$; between Me-26 $\left(\delta_{\mathrm{H}} 1.075\right)$ and Me-28 $\left(\delta_{\mathrm{H}}\right.$ 1.083) and $\mathrm{H}-13 \beta\left(\delta_{\mathrm{H}} 2.48\right)$; between Me-27 $\left(\delta_{\mathrm{H}} 1.05\right)$ and $\mathrm{H}-9 \alpha$; between Me-28 $\left(\delta_{\mathrm{H}} 1.083\right)$ and Me-26 and OMe $\left(\delta_{\mathrm{H}} 3.22\right)$; between Me-29 $\left(\delta_{\mathrm{H}} 1.11\right)$ and $\mathrm{H}-21 \alpha\left(\delta_{\mathrm{H}} 3.77\right)$ and OMe; and between $\mathrm{H}-21\left(\delta_{\mathrm{H}} 3.77\right)$ and Me-29 and $\mathrm{H}-22 \alpha$. However, a cross peak was not observed between Me-28 and H-21. Therefore, the 18,19-epoxy ring and secondary methoxy group at the C-21 in the $\beta$ orientation and the structure of 1 was elucidated as $18 \beta, 19 \beta$-epoxy-21 $\beta$-methoxylupan-3 $\beta$-yl acetate.

Compound (2) was obtained as colorless crystals, and its molecular formula was established as $\mathrm{C}_{32} \mathrm{H}_{50} \mathrm{O}_{3}\left([\mathrm{M}]^{+} ; m / z 482.3759\right.$, calcd. for 482.3760$)$ by HREIMS. IR and UV spectra revealed the presence of an ester group and an $\alpha \beta$-unsaturated six-membered ring ketone at $\nu_{\max } 1733,1247$, and $1665 \mathrm{~cm}^{-1}$ and $\lambda_{\max }$ at $245.0 \mathrm{~nm}\left(\log \varepsilon\right.$ 3.97). The ${ }^{1} \mathrm{H}$ - and ${ }^{13} \mathrm{C}-\mathrm{NMR}$ spectra of 2 (Table 2) indicated the presence of six tertiary methyls $\left(\delta_{\mathrm{H}} 0.88,0.96,1.06(6 \mathrm{H}), 1.19,1.20\right.$ (each s)), two secondary methyls $\left(\delta_{\mathrm{H}}\right.$ $0.92(\mathrm{~d}), 1.07(\mathrm{~d}))$, an acetyl methyl $\left(\delta_{\mathrm{H}} 2.07(\mathrm{~s})\right)$, eight methylenes, six methines including an oxymethine $\left(\delta_{\mathrm{H}} 4.47(\mathrm{dd}), \delta_{\mathrm{C}} 80.6(\mathrm{~d})\right)$, five $\mathrm{sp}^{3}$ quaternary carbons, and an $\alpha \beta$-unsaturated six-membered ring ketone $\left(\delta_{\mathrm{H}} 5.84(\mathrm{~d}), \delta_{\mathrm{C}} 123.9(\mathrm{~d}), 170.3(\mathrm{~s}), 199.8(\mathrm{~s})\right)$. In the ${ }^{1} \mathrm{H}-{ }^{1} \mathrm{H}$ COSY spectrum, correlations of $\mathrm{H}_{2}-1-\mathrm{H}-3 ; \mathrm{H}-9-\mathrm{H}_{2}-12 ; \mathrm{H}_{2}-15-\mathrm{H}_{2}-16$; and $\mathrm{H}-18-\mathrm{H}_{2}-22$ were observed (Figure 3). The planar structure of 2 was established by a comprehensive analysis of 1D and 2D NMR spectra, particularly the HMBC spectrum. Selected HMBC correlations are shown in Figure 3. Strong correlations were observed from Me-23 $\left(\delta_{\mathrm{H}} 1.20(\mathrm{~s})\right)$ and Me-24 $\left(\delta_{\mathrm{H}} 1.19(\mathrm{~s})\right)$ to C-3 $\left(\delta_{\mathrm{C}} 80.6(\mathrm{~d})\right), \mathrm{C}-4$ and C-5; from Me-25 $\left(\delta_{\mathrm{H}} 0.88(\mathrm{~s})\right)$ to C-1, C-5, C-9 and C-10; from Me-26 ( $\left.\delta_{\mathrm{H}} 1.06(\mathrm{~s})\right)$ to C-8 $\left(\delta_{\mathrm{C}} 170.3(\mathrm{~s})\right), \mathrm{C}-13, \mathrm{C}-14$ and C-15; from Me-27 $\left(\delta_{\mathrm{H}} 0.96(\mathrm{~s})\right)$ to $\mathrm{C}-12, \mathrm{C}-13, \mathrm{C}-14$ and C-17; from Me-28 $\left(\delta_{\mathrm{H}} 1.06(\mathrm{~s})\right)$ to C-16, C-17, C-18 and C-22; from Me-29 $\left(\delta_{\mathrm{H}} 1.07(\mathrm{~d})\right)$ to C-18, C-19 and C-20; from Me-30 $\left(\delta_{\mathrm{H}} 0.92(\mathrm{~d})\right)$ to C-19, C-20 and C-21; from H-7 $\left(\delta_{\mathrm{H}} 5.84(\mathrm{~d})\right)$ to $\mathrm{C}-5, \mathrm{C}-6\left(\delta_{\mathrm{C}} 199.8(\mathrm{~s})\right), \mathrm{C}-8, \mathrm{C}-9$ and C-14; and from H-18 $\left(\delta_{\mathrm{H}} 1.33\right)$ to C-12, C-13, C-14, C-18, C-19, C-20, C-27 and C-28. Based on the above spectral data, in addition to the ${ }^{1} \mathrm{H}-\mathrm{NMR}$ chemical shift in 2 compared with previous data on baurerenyl acetate [7,8], the plain structure was assumed to be $D: C$-friedours-7-ene-6-one (baueran-7-en-6-one). The relative configuration of 2 was established in the NOESY experiment. Strong NOESY correlations between Me-23 and H-3 $\alpha$; between Me-25 and Me-24 and Me-26; between Me-27 and H-9 $\alpha$ and Me-30; between $\mathrm{H}-5 \alpha$ and $\mathrm{H}-9 \alpha$ : between $\mathrm{H}-7$ and $\mathrm{H}-15 \alpha$ and $\mathrm{H}-15 \beta$; between $\mathrm{H}-18$ and Me-26, Me-28 and Me-29; between H-19 and Me-27; and between H-20 and Me-28 revealed an acetyl group at C-3 in the $\beta$ orientation, $\mathrm{H}-18$ in the $\beta$ orientation, and Me-19 and Me-20 in the $\beta$ and $\alpha$ orientations, respectively. Therefore, the structure of 2 was established as $3 \beta$-acetoxybauer-7-en-6-one. Natori et al. synthesized $3 \beta$-acetoxy-9 $\alpha$-bauer-7-en-6-one (XIII) from the oxidation of bauerenyl acetate, and confirmed the structure of XIII from a comparison between $3 \beta$-acetoxy-9 $\beta$-bauer-7-en-6-one (XII) and XIII [9]. However, a marked difference was found in the ${ }^{1} \mathrm{H}-\mathrm{NMR}$ chemical shifts in 2 and XIII; therefore, the structure of XIII does not appear to be reasonable due to the lack of sufficient evidence. On the other hand, Yen isolated $3 \beta$-acetoxy-9 $\beta$-bauer-7-en-6-one from the stem bark of Hiptage benghalensis, and the chemical shift value of ${ }^{1} \mathrm{H}-\mathrm{NMR}$ was similar to that described above for compound XII [10]. 
Table 1. ${ }^{1} \mathrm{H}-(600 \mathrm{MHz})$ and ${ }^{13} \mathrm{C}-(150 \mathrm{MHz}) \mathrm{NMR}$ data of compounds 1-3.

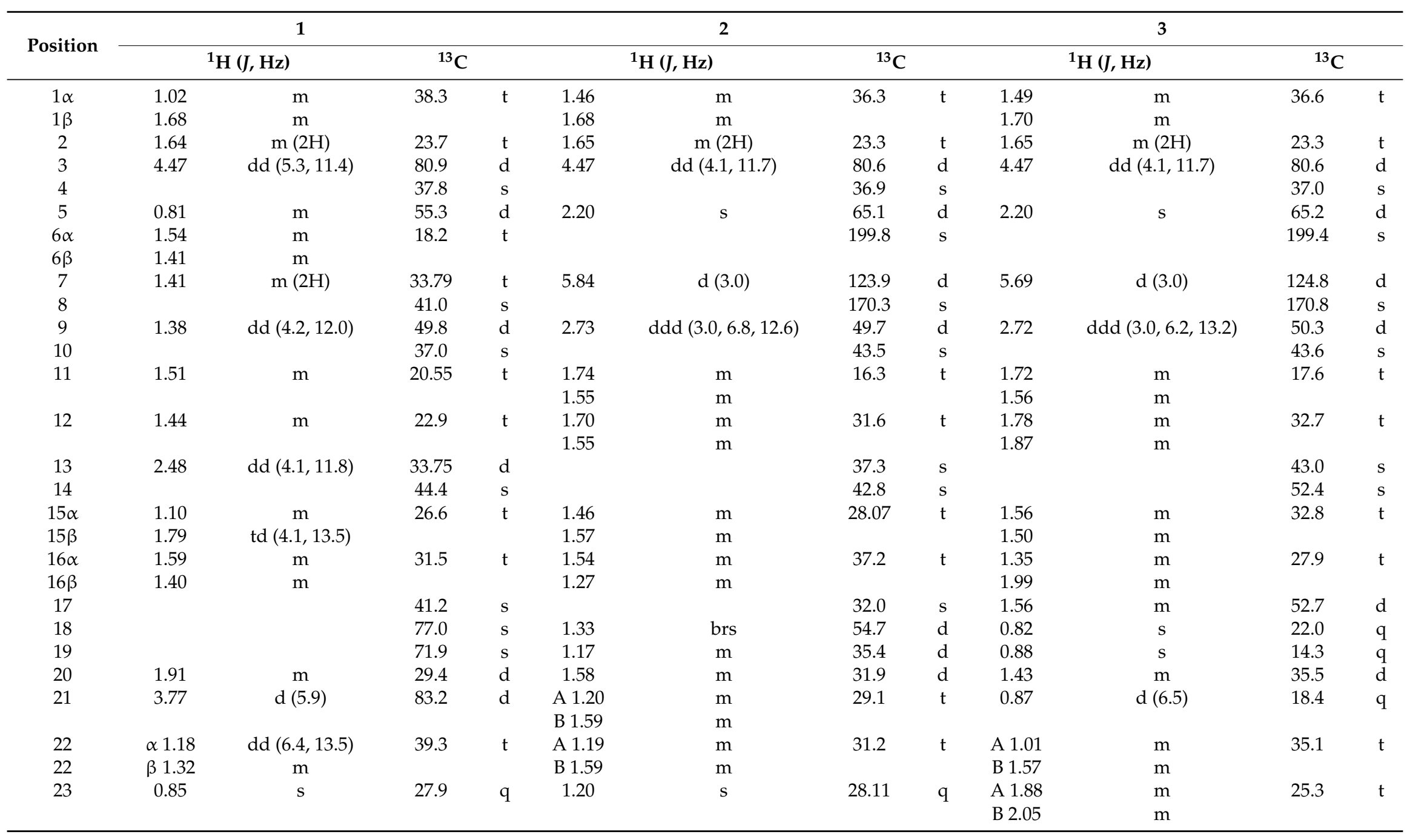


Table 1. Cont.

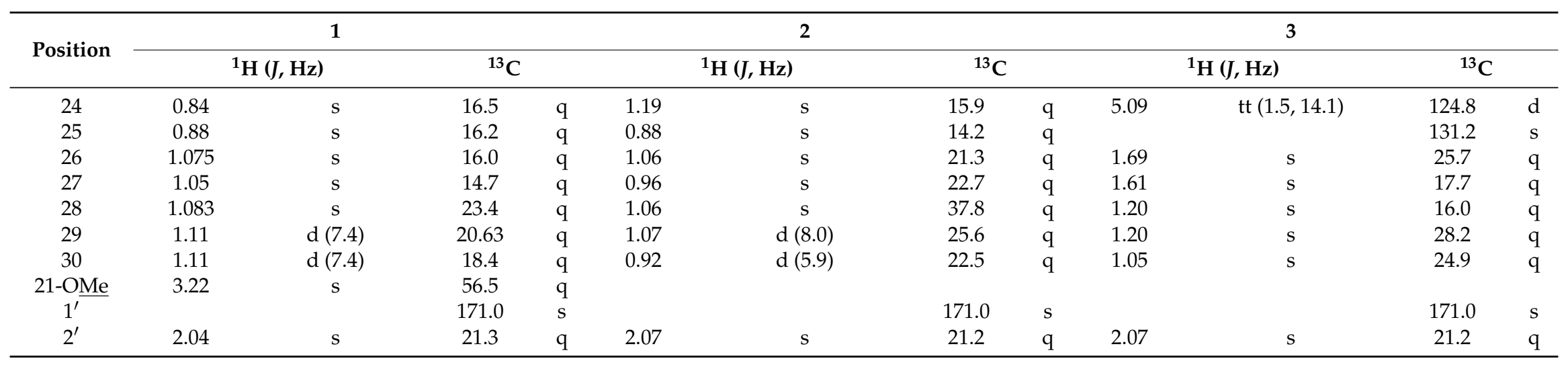




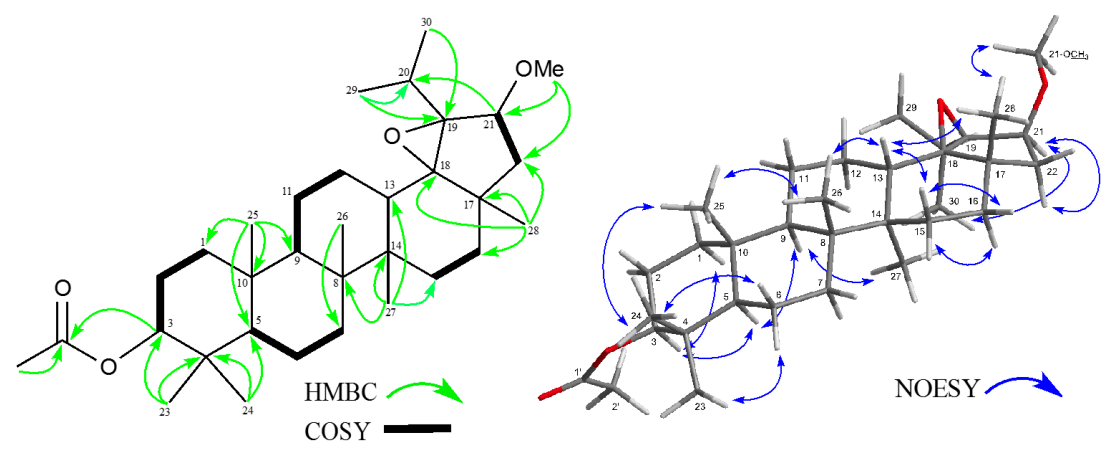

Figure 2. Key HMBC, COSY and NOESY correlations for $\mathbf{1 .}$

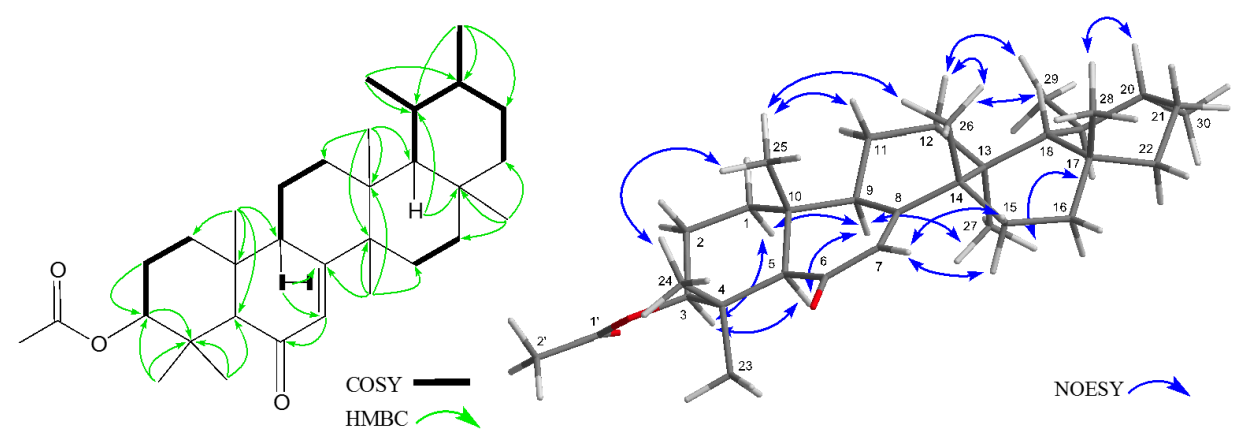

Figure 3. Key HMBC, COSY and NOESY correlations for 2.

Compound 3, a colorless crystal, had the molecular formula of $\mathrm{C}_{32} \mathrm{H}_{50} \mathrm{O}_{3}\left(\mathrm{~m} / z 482.3764\right.$ [M] ${ }^{+}$, calcd 482.3760) by HREIMS. The IR spectrum and UV absorption band showed the presence of an ester group $\left(\nu_{\max } 1731 \mathrm{~cm}^{-1}\right)$ and an $\alpha \beta$-unsaturated six-membered ring ketone $\left[\nu_{\max } 1664 \mathrm{~cm}^{-1}, \lambda_{\max }=244.5 \mathrm{~nm}\right.$ ( $\log \varepsilon$ 3.99)]. The ${ }^{1} \mathrm{H}$ - and ${ }^{13} \mathrm{C}-\mathrm{NMR}$ spectra (Table 1$)$ exhibited signals assignable to five tertiary methyl groups $\left(\delta_{\mathrm{H}} 0.82,0.88,1.05,1.20(6 \mathrm{H})\right.$ (each s)); a secondary methyl $\left(\delta_{\mathrm{H}} 0.87(\mathrm{~d})\right)$, two vinyl methyls $\left(\delta_{\mathrm{H}} 1.61,1,69(\right.$ each s) $)$, an acetyl $\left(\delta_{\mathrm{H}} 2.07(3 \mathrm{H}, \mathrm{s}), \delta_{\mathrm{C}} 171.0(\mathrm{~s})\right)$; eight sp ${ }^{3}$ methylene, five $\mathrm{sp}^{3}$ methines including an oxymethine $\left(\delta_{\mathrm{H}} 4.47(\mathrm{dd})\right)$; four sp ${ }^{3}$ quaternary carbons, two trisubstituted olefins $\left(\delta_{\mathrm{H}} 5.09(\mathrm{tt}), \delta_{\mathrm{C}} 124.8(\mathrm{~d}), 131.2(\mathrm{~s})\right),\left(\delta_{\mathrm{H}} 5.69(\mathrm{~d}), \delta_{\mathrm{C}} 124.8(\mathrm{~d}), 170.8(\mathrm{~s})\right)$, and an $\alpha \beta$-unsaturated ketone $(199.4(\mathrm{~s}))$. Cross peaks in the ${ }^{1} \mathrm{H}^{-1} \mathrm{H}$ COSY spectrum are shown in bold lines in Figure 4 . In the HMBC spectrum, these cross peaks were observed from Me-18 $\left(\delta_{\mathrm{H}} 0.82(\mathrm{~s})\right) / \mathrm{C}-12, \mathrm{C}-13, \mathrm{C}-17$; Me-19 $\left(\delta_{\mathrm{H}} 0.88(\mathrm{~s})\right) / \mathrm{C}-1, \mathrm{C}-9, \mathrm{C}-10 ; \mathrm{Me}-21\left(\delta_{\mathrm{H}} 0.87(\mathrm{~d})\right) / \mathrm{C}-17, \mathrm{C}-20, \mathrm{C}-22 ; \mathrm{Me}-26$ and Me-27 $\left(\delta_{\mathrm{H}} 1.69\right.$ and 1.61 $($ each $3 \mathrm{H}, \mathrm{s})) / \mathrm{C}-24\left(\delta_{\mathrm{C}} 124.8(\mathrm{~d})\right), \mathrm{C}-25\left(\delta_{\mathrm{C}} 131.2(\mathrm{~s})\right)$; Me-28 and Me-29 $\left(\delta_{\mathrm{H}} 1.20(6 \mathrm{H}, \mathrm{s})\right) / \mathrm{C}-3\left(\delta_{\mathrm{C}} 80.6\right.$ (d)), C-4, C-5; Me-30 ( $\left.\delta_{\mathrm{H}} 1.05(\mathrm{~s})\right) / \mathrm{C}-8, \mathrm{C}-13, \mathrm{C}-14, \mathrm{C}-15 ; \mathrm{H}-7\left(\delta_{\mathrm{H}} 5.69(\mathrm{~d})\right) / \mathrm{C}-5, \mathrm{C}-6\left(\delta_{\mathrm{C}} 199.4(\mathrm{~s})\right), \mathrm{C}-8$, C-9, C-14; H-24 $\left(\delta_{\mathrm{H}} 5.09(\mathrm{tt})\right) / \mathrm{C}-22, \mathrm{C}-23, \mathrm{C}-25\left(\delta_{\mathrm{C}} 131.2(\mathrm{~s})\right), \mathrm{C}-26, \mathrm{C}-27$. The relative configuration of 3 was elucidated on the basis of NOESY correlations (Figure 4). Intense NOESY correlations between Me-18 and H-16 $\alpha$; between Me-19 and Me-29, Me-30, and H-11 $\beta$; between Me-30 and Me-19, H-11 $\beta$, H-12 $\beta, H-16 \beta$ and H-17; between $\mathrm{H}-3$ and $\mathrm{H}-1 \alpha$, and $\mathrm{H}-5 \alpha$; between $\mathrm{H}-7$ and $\mathrm{H}-15 \alpha$, Me-19, and Me-30; between $\mathrm{H}-16 \alpha$ and Me-18, Me-21, and H-15 $\alpha$; between $\mathrm{H}-20$ and $\mathrm{H}-16 \alpha$ and Me-18, indicated that the acetyl group at the $\mathrm{C}-3$ position was in the $\beta$ orientation, as $\mathrm{H}-17$ was $\beta$-orientation. However, Me- 18 and Me- 21 were in the $\alpha$ orientation. More importantly, NOESY cross peaks for H-12 $\beta$ with H-17; Me-21 with H-16 $\alpha$ and H-16 $\beta$; and H-24 with H-12 $\beta, \mathrm{H}-17$ and Me-27, which suggested that 3 would be a euphane-type triterpene. Pettit et al. reported five euphane triterpenoids named Meliastatins 1-5 from Melia dubia, and the NOESY spectrum of Meliastatins resembles that of 3 [11]. The ${ }^{13} \mathrm{C}-\mathrm{NMR}$ chemical shift values of the side chain of $\mathbf{3}$ had similar literature data of butyrospermol [12] and kansenone [13]. Based on these results and the biogenetical consideration [14], 3 was established as 
$3 \beta$-acetoxyeupha-7,24-dien-6-one, isolated for the first time. Although euphane-type triterpenoids have been known for a long time, they are not present in abundant amounts in nature.

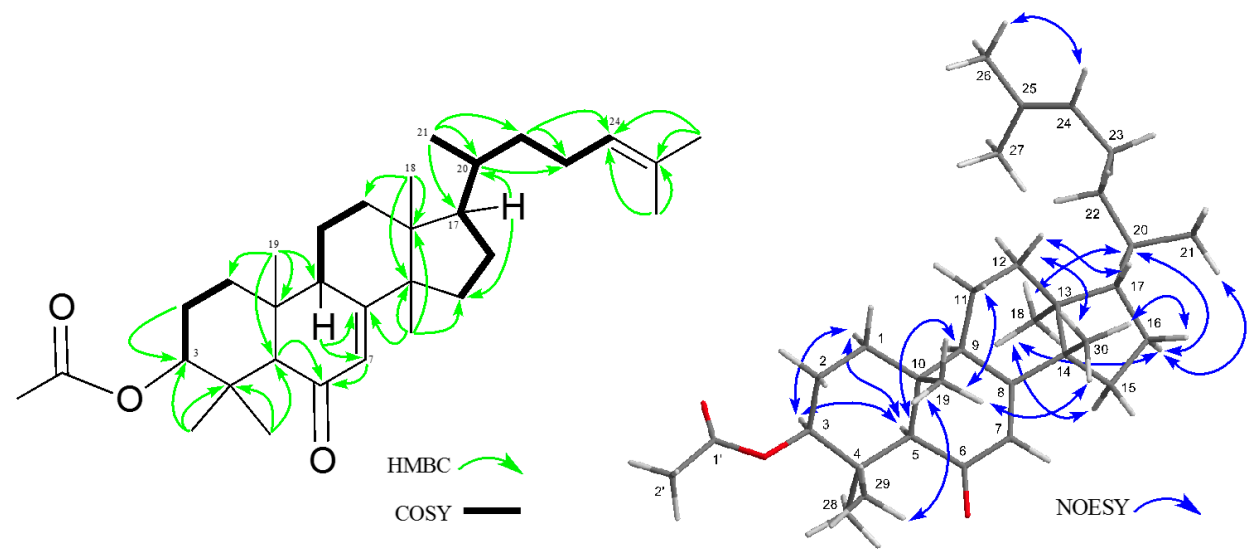

Figure 4. Key HMBC, COSY, and NOESY correlations for 3.

Macrophages may be a potential therapeutic target for inflammatory diseases [15]. Activated macrophages release pro-inflammatory mediators, such as NO, reactive oxygen species, interleukin-1 beta, tumor necrosis factor-alpha, and other inflammatory mediators, which play important roles in biological defenses. However, the overexpression of these mediators has been implicated in diseases such as osteoarthritis, rheumatoid arthritis, and diabetes, because the increased production of pro-inflammatory mediators has been shown to induce severe or chronic inflammation [15]. Ten triterpenoids and L-NMMA — an inducible nitric oxide synthase (iNOS) inhibitor-were evaluated for their inhibitory effects on NO production (Table 2). Among the compounds tested, 4, 6, 7, 8, and 10 exhibited NO inhibitory activities. Of these, 7 and 8 exhibited no cytotoxicity at 1-30 $\mu \mathrm{M}$. Although 4, 6, and 10 exhibited some cytotoxicity at higher concentrations, they had similar inhibitory effects on NO production by triterpenoids from roots of Taraxacum officinale superior inhibitory activities to L-NMMA at non-toxic concentrations (4 at 3-10 $\mu \mathrm{M} ; 6$ at 1 and $3 \mu \mathrm{M} ; 10$ at 3 and $10 \mu \mathrm{M}$ ).

\section{Experimental Section}

\subsection{General Procedures}

Melting points were measured on a Yanagimoto micro-melting point apparatus (Yanagimoto, Kyoto, Japan) and were uncorrected. Optical rotations were measured using a JASCO DIP-1000 digital polarimeter (JASCO, Tokyo, Japan). IR spectra were recorded using a Perkin-Elmer 1720X FTIR spectrophotometer (Perkin-Elmer Inc., Wellesley, MA, USA). ${ }^{1} \mathrm{H}$ - and ${ }^{13} \mathrm{C}-\mathrm{NMR}$ spectra were obtained on an Agilent VNMRS 600 spectrometer (Agilent Technologies, Santa Clara, CA, USA) with standard pulse sequences, operating at 600 and $150 \mathrm{MHz}$, respectively. $\mathrm{CDCl}_{3}$ was used as the solvent, and tetramethylsilane (TMS) as the internal standard. HREIMS were recorded on a JEOL-7000 mass spectrometer (JEOL, Tokyo, Japan). Column chromatography was performed over silica gel (70-230 mesh, Merck, Darmstadt, Germany), while medium pressure liquid chromatography (MPLC) was conducted with silica gel (230-400 mesh, Merck). HPLC was run on a JASCO PU-1586 instrument (JASCO, Tokyo, Japan) equipped with a differential refractometer (RI 1531). Fractions obtained from column chromatography were monitored by thin layer chromatography (TLC) (silica gel $60 \mathrm{~F}_{254}$, Merck). 


\subsection{Plant Material}

The roots of T. officinale (Compositae) were collected in Takatsuki city, Osaka, Japan in April 2014. A voucher specimen (TR-01) was deposited in the Herbarium of the Laboratory of Medicinal Chemistry, Osaka University of Pharmaceutical Sciences.

Table 2. Inhibitory effects of NO production by triterpenoids from roots of Taraxacum officinale.

\begin{tabular}{|c|c|c|c|c|c|}
\hline & \multicolumn{4}{|c|}{ Produced NO \% (Cell Viavility \%) ${ }^{a}$} & \multirow[b]{2}{*}{$\mathrm{IC}_{50}(\mu \mathrm{M}$} \\
\hline & $\mathbf{1} \mu \mathbf{M}$ & $3 \mu \mathbf{M}$ & $10 \mu \mathbf{M}$ & $30 \mu \mathbf{M}$ & \\
\hline 1 & $\begin{array}{c}94.8 \pm 1.2 \\
(95.0 \pm 0.7)\end{array}$ & $\begin{array}{c}101.4 \pm 0.7 \\
(104.2 \pm 1.3)\end{array}$ & $\begin{array}{c}90.5 \pm 2.4 \\
(102.6 \pm 0.7)\end{array}$ & $\begin{array}{c}95.7 \pm 4.6 \\
(107.4 \pm 2.0)\end{array}$ & $>30$ \\
\hline 2 & $\begin{array}{c}95.6 \pm 2.7 \\
(100.0 \pm 1.3)\end{array}$ & $\begin{array}{c}100.7 \pm 2.6 \\
(102.2 \pm 0.3)\end{array}$ & $\begin{array}{l}86.5 \pm 1.4^{* *} \\
(105.1 \pm 0.3)\end{array}$ & $\begin{array}{l}71.4 \pm 1.8^{* *} \\
(105.7 \pm 2.0)\end{array}$ & $>30$ \\
\hline 3 & $\begin{array}{c}100.6 \pm 2.6 \\
(100.0 \pm 1.4)\end{array}$ & $\begin{array}{c}93.7 \pm 1.4 \\
(94.6 \pm 8.2)\end{array}$ & $\begin{array}{c}93.3 \pm 1.6 \\
(104.2 \pm 0.7)\end{array}$ & $\begin{array}{c}93.1 \pm 0.9 \\
(103.8 \pm 1.0)\end{array}$ & $>30$ \\
\hline 4 & $\begin{array}{c}83.6 \pm 0.9^{* *} \\
(98.4 \pm 0.9)\end{array}$ & $\begin{array}{c}76.8 \pm 2.5^{* *} \\
(97.9 \pm 0.3)\end{array}$ & $\begin{array}{c}66.0 \pm 0.8^{* *} \\
(92.7 \pm 1.0)\end{array}$ & $\begin{array}{c}35.4 \pm 2.2^{* *} \\
(49.5 \pm 0.7)\end{array}$ & 16.9 \\
\hline 5 & $\begin{array}{l}110.3 \pm 5.2 \\
(98.4 \pm 3.1)\end{array}$ & $\begin{array}{l}106.1 \pm 3.2 \\
(94.8 \pm 3.9)\end{array}$ & $\begin{array}{c}94.9 \pm 4.3 \\
(90.7 \pm 1.8)\end{array}$ & $\begin{array}{c}92.7 \pm 4.7 \\
(88.9 \pm 2.3)\end{array}$ & $>30$ \\
\hline 6 & $\begin{array}{c}83.4 \pm 1.5^{* *} \\
(99.8 \pm 0.1)\end{array}$ & $\begin{array}{c}75.0 \pm 3.2 * * \\
(93.7 \pm 1.1)\end{array}$ & $\begin{array}{c}65.4 \pm 0.5^{* *} \\
(76.7 \pm 0.7)\end{array}$ & $\begin{array}{c}36.3 \pm 0.6^{* *} \\
(66.7 \pm 1.2)\end{array}$ & 17.0 \\
\hline 7 & $\begin{array}{l}101.0 \pm 1.0 \\
(98.3 \pm 2.6)\end{array}$ & $\begin{array}{c}101.0 \pm 2.5 \\
(103.0 \pm 2.4)\end{array}$ & $\begin{array}{c}89.8 \pm 1.1^{* *} \\
(99.7 \pm 3.8)\end{array}$ & $\begin{array}{c}66.8 \pm 0.8^{* *} \\
(99.8 \pm 3.0)\end{array}$ & $>30$ \\
\hline 8 & $\begin{array}{l}102.9 \pm 0.7 \\
(99.9 \pm 0.1)\end{array}$ & $\begin{array}{c}105.0 \pm 3.1 \\
(100.4 \pm 0.1)\end{array}$ & $\begin{array}{c}90.2 \pm 7.1 \\
(100.5 \pm 0.2)\end{array}$ & $\begin{array}{l}64.1 \pm 3.3^{* *} \\
(103.0 \pm 1.6)\end{array}$ & $>30$ \\
\hline 9 & $\begin{array}{c}98.4 \pm 3.9 \\
(99.3 \pm 0.2)\end{array}$ & $\begin{array}{l}100.4 \pm 1.6 \\
(98.8 \pm 0.2)\end{array}$ & $\begin{array}{c}109.1 \pm 2.0 * * \\
(99.1 \pm 0.4)\end{array}$ & $\begin{array}{c}108.2 \pm 4.7^{*} \\
(99.9 \pm 0.6)\end{array}$ & $>30$ \\
\hline 10 & $\begin{array}{c}93.8 \pm 1.8 \\
(108.3 \pm 4.7)\end{array}$ & $\begin{array}{l}81.6 \pm 3.7^{* *} \\
(100.4 \pm 0.2)\end{array}$ & $\begin{array}{l}67.5 \pm 2.4 * * \\
(100.2 \pm 0.1)\end{array}$ & $\begin{array}{c}37.0 \pm 1.8^{* *} \\
(2.6 \pm 0.4)\end{array}$ & 18.4 \\
\hline L-NMMA $^{\mathrm{b}}$ & $\begin{array}{c}93.3 \pm 2.2 \\
(101.5 \pm 0.9)\end{array}$ & $\begin{array}{c}91.4 \pm 0.8 \\
(101.9 \pm 0.4)\end{array}$ & $\begin{array}{c}68.9 \pm 4.5^{* *} \\
(98.5 \pm 0.9)\end{array}$ & $\begin{array}{l}43.1 \pm 1.1^{* *} \\
(109.4 \pm 0.5)\end{array}$ & 23.9 \\
\hline
\end{tabular}

\footnotetext{
a Produced NO (\%) and cell viability (\%) were determined based on the absorbance at $570 \mathrm{~nm}$, respectively, by comparison with values for DMSO (100\%). Each value represents the mean \pm standard error (S.E.) of four determinations. Significant differences from the vehicle control group shown as ${ }^{*} p<0.05$ and ${ }^{* *} p<0.01$; b Positive control.
}

\subsection{Isolation of Compounds $\mathbf{1}-\mathbf{3}$}

The roots of $T$. officinale $\left(5.81 \mathrm{~kg}\right.$ ) were extracted with $\mathrm{MeOH}$ at $60{ }^{\circ} \mathrm{C}$ for 10 days, and the dried extract obtained $(890 \mathrm{~g})$ was partitioned between EtOAc and $\mathrm{H}_{2} \mathrm{O}$. The organic layer $(290 \mathrm{~g})$ was condensed in vacuo and subjected to column chromatography (silica gel (3 kg); hexane:EtOAc $(5: 1 \rightarrow 1: 1 \rightarrow 0: 1)$ and EtOAc:MeOH (1:1 $\rightarrow 0: 1))$, affording residues A (Fr. No. 1 and 2, 0.72 g), B (Fr. No. 3, 2.42 g), C (Fr. No. 4 and 5, 5.17 g), D (Fr. No. 6-10, 3.37 g), E (Fr. No. 11, 0.44 g), F (Fr. No. 12, 1.84 g), G (Fr. No. 13, 4.87 g), H (Fr. No. 14, 6.29 g), I (Fr. No. 15, 4.64 g), J (Fr. No. 16, 1.89 g), K (Fr. No. 17-20, 1.46 g), L (Fr. No. 21-27, 7.02 g), M (Fr. No. 28-40, 1.98 g), N (Fr. No. 41-52, 2.32 g), O (Fr. No. 53-66, 42.48 g), P (Fr. No. 67-78, 1.49 g), Q (Fr. No. 79-84, 0.54 g), R (Fr. No. 85-94, 30.57 g), and S (Fr. No. 95-108, 5.68 g). Residue C was rechromatographed over silica gel to give a triterpene fraction, which was subjected to HPLC (ODS, 95\% MeOH) to afford compounds 1 (1.38 mg) and $9(1.12 \mathrm{mg})$ [16]. Residue D was rechromatographed over silica gel to give a triterpene fraction, which was subjected to HPLC (ODS, $95 \% \mathrm{MeOH})$ to afford compounds $2(1.60 \mathrm{mg}), 3(2.40 \mathrm{mg})$, 5 (1.61 mg) [17], 8 (1.39 mg) [18], and $10(2.82 \mathrm{mg})$ [19]. Residue L was rechromatographed over silica gel to give a triterpene fraction, which was subjected to HPLC (ODS, 95\% MeOH) to afford compounds $4(20.23 \mathrm{mg})$ [5] and 7 (1.06 mg) [5]. Residue O was rechromatographed over silica gel to give a triterpene fraction, which was subjected to HPLC (ODS, 95\% MeOH) to afford compound 6 (1.94 mg) [20]. 


\subsection{Analytical Data}

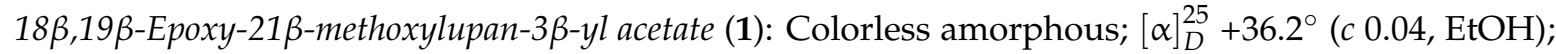
HREIMS $m / z$ : $514.4022[\mathrm{M}]^{+}\left(\mathrm{C}_{33} \mathrm{H}_{54} \mathrm{O}_{4}\right.$, calcd. for 514.4022); IR (KBr) $v_{\max } \mathrm{cm}^{-1}: 2956,2925,1739$ $(\mathrm{O}-\mathrm{C}=\mathrm{O}), 1456,1381,1367,1246 ;{ }^{1} \mathrm{H}$ - and ${ }^{13} \mathrm{C}-\mathrm{NMR}$, see Table 1 . EIMS $\mathrm{m} / \mathrm{z}$ (relative intensity (rel. int.)): $514[\mathrm{M}]^{+}(100), 483$ (26), 416 (45), 325 (4), 233 (6), 191 (9), 135 (12).

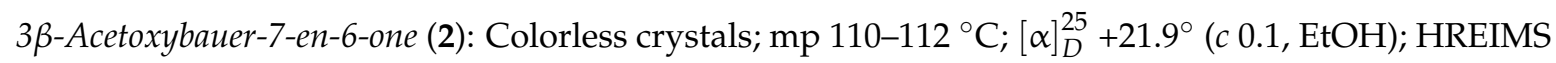
$m / z: 482.3759$ [M] $^{+}\left(\mathrm{C}_{32} \mathrm{H}_{50} \mathrm{O}_{3}\right.$, calcd for 482.3760); UV $\lambda_{\max }(\mathrm{EtOH}) \mathrm{nm}(\log \varepsilon): 245.0$ (3.97); IR (KBr) $v_{\max } \mathrm{cm}^{-1}:$ 2954, 2869, 1733, and $1247(\mathrm{O}-\mathrm{C}=\mathrm{O}), 1665(\mathrm{O}=\mathrm{C}-\mathrm{C}=\mathrm{C}), 1466,1388 ;{ }^{1} \mathrm{H}-$ and ${ }^{13} \mathrm{C}-\mathrm{NMR}$, see Table 1. EIMS $m / z$ (rel. int.): 482 [M] $^{+}$(100), 422 [M - HOAc] $]^{+}$(48), 407 (31), 379 (30), 300 (45), 219 (46), 206 (44), 203 (42), 191 (35), 161 (40).

$3 \beta$-Acetoxyeupha-7,24-dien-6-one (3): Colorless crystals; mp $140-143{ }^{\circ} \mathrm{C} ;[\alpha]_{D}^{25}-38.1^{\circ}$ (c 0.04, EtOH); HREIMS m/z: $482.3764[\mathrm{M}]^{+}\left(\mathrm{C}_{32} \mathrm{H}_{50} \mathrm{O}_{3}\right.$, calcd. for 482.3760); UV $\lambda_{\max }(\mathrm{EtOH}) \mathrm{nm}(\log \varepsilon): 244.5$ (3.99); IR $(\mathrm{KBr}) \nu_{\max } \mathrm{cm}^{-1}: 2958,1731$, and $1247(\mathrm{O}-\mathrm{C}=\mathrm{O}), 1664(\mathrm{O}=\mathrm{C}-\mathrm{C}=\mathrm{C}), 1437,1384 ;{ }^{1} \mathrm{H}-$ and ${ }^{13} \mathrm{C}-\mathrm{NMR}$, see Table 1. EIMS $m / z$ (rel. int.): $482[\mathrm{M}]^{+}$(59), 467 (56), $422\left[\mathrm{M}-\mathrm{HOAc}^{+}\right.$(26), 407 (34), 369 (100), 300 (43), 217 (16), 206 (44), 189 (17), 161 (45).

\subsection{Determination of RAW264.7 Cell Proliferation}

RAW264.7 cell proliferation was examined in accordance with a previously reported method [21]. Briefly, RAW264.7 cells $\left(5 \times 10^{4}\right.$ cells in $\left.100 \mu \mathrm{L}\right)$ were seeded on a 96-well microplate and incubated for $24 \mathrm{~h}$. Dulbecco's modified eagle's medium (DMEM)-containing test samples (100 $\mu \mathrm{L}$ total volume, final concentration of 30,10,3, or $1 \mu \mathrm{M}$ ) dissolved in dimethyl sulfoxide (DMSO, final concentration $0.2 \%$ ) was added. After being treated for $24 \mathrm{~h}$, thiazolyl blue tetrazolium bromide (MTT) solution was added. After a 3-h incubation, 20\% sodium dodecyl sulfate in $0.1 \mathrm{M} \mathrm{HCl}$ was added to dissolve the formazan produced in the cells. Absorbance in each well was read at $570 \mathrm{~nm}$ using a microplate reader. The optical density of vehicle control cells was assumed to be $100 \%$.

\subsection{Inhibitory Assay of NO Production}

An inhibitory assay of NO production was examined in accordance with a previously reported method [22] with minor modifications. Briefly, RAW264.7 cells $\left(5 \times 10^{4}\right.$ cells in $\left.100 \mu \mathrm{L}\right)$ were seeded on a 96-well microplate and incubated for $24 \mathrm{~h}$. DMEM-containing test samples $(100 \mu \mathrm{L}$ total volume, final concentration of 30, 10, 3, or $1 \mu \mathrm{M}$ ) dissolved in DMSO (final concentration $0.2 \%$ ) and LPS (final concentration of $5 \mu \mathrm{g} / \mathrm{mL}$ ) was added. After being treated for $24 \mathrm{~h}$, the supernatant of the culture medium was transferred to another 96-well microplate, and $50 \mu \mathrm{L}$ of $0.15 \% \mathrm{~N}$-(1-naphtyl)ethylenediamine in $\mathrm{H}_{2} \mathrm{O}$ and $1.5 \%$ sulfanilamide in $7.5 \%$ phosphoric acid were then added. After being incubated for $30 \mathrm{~min}$, absorbance in each well was read at $570 \mathrm{~nm}$ using a microplate reader. The optical density of vehicle control cells was assumed to be $100 \%$

\section{Conclusions}

A novel lupane-type triterpenoid (1), as well as a novel bauerane-type triterpenoid (2) and a novel euphane-type triterpenoid (3) were isolated from the roots of T. officinale (Compositae), together with seven known triterpenoids (4-10). Their structures were elucidated by spectroscopic analyses. In the NO inhibitory assay, Compounds 4, 6, and 10 exhibited similar NO inhibitory activities (IC ${ }_{50} 4$ : $16.9 \mu \mathrm{M}$; 6: $17.0 \mu \mathrm{M}$; 10: $18.4 \mu \mathrm{M}$ ) to L-NMMA ( $\left.\mathrm{IC}_{50} 23.9 \mu \mathrm{M}\right)$. These compounds did not exhibit cytotoxicity at an effective concentration ( 4 and 10 at $1-10 \mu \mathrm{M} ; 6$ at 1 and $3 \mu \mathrm{M})$. These results suggest that compounds 4,6 , and 10 have potential as anti-inflammatory disease agents. 
Acknowledgments: We thank Katsuhiko Minoura and Mihoyo Fujitake (this university) for NMR and MS measurements.

Author Contributions: R. Tanaka and T. Kikuchi prepared the manuscript. T. Kikuchi, A. Tanaka, and M. Uriuda contributed to the isolation and structural elucidation. T. Kikuchi performed the evaluation of bioactivities. T. Yamada supervised the whole research project.

Conflicts of Interest: The authors declare no conflict of interest.

\section{References}

1. Singh, A.; Malhotra, S.; Subban, R. Dandelion (Taraxacum officinale)-hepatoprotective herb with therapeutic potential. Pharmacogn. Rev. 2008, 2, 163-167.

2. Nowak, G.; Panak, H. Forms of potassium and sodium in some species of grasses and herbage. Acta Agrobot. 1985, 35, 87-99. [CrossRef]

3. Gonzalez-Castejon, M.; Garcia-Carrasco, B.; Fernandez-Dacosta, R.; Davalos, A.; Rodriguez-Casado, A. Reduction of adipogenesis and lipid accumulation by Taraxacum officinale (dandelion) extracts in 3T3L1 adipocytes: An in vivo study. Phytother. Res. 2014, 28, 745-752. [CrossRef] [PubMed]

4. Cui, Y. Chinese Medicinal Capsule and Its Preparation Method. CN Patent 1660189 A 20050831, 2005.

5. Saeki, D.; Yamada, T.; In, Y.; Kajimoto, T.; Tanaka, R.; Iizuka, Y.; Nakane, T.; Takano, A.; Masuda, K. Officinatrione: An unusual (17S)-17,18-seco-lupane skeleton, and four novel lupane-type triterpenoids from the roots of Taraxacum officinale. Tetrahedron 2013, 69, 1583-1589. [CrossRef]

6. Matsunaga, S.; Morita, R. Hopenol-b, a triterpene alcohol from Euphorbia supina. Phytochemistry 1983, 22, 605-606. [CrossRef]

7. Chakravarty, A.K.; Das, B.; Masuda, K.; Arai, Y.; Shiojima, K. Peracid induced oxidative rearrangements of triterpenoids: Products of new skeleton from bauerenyl acetate. Tetrahedron 1998, 54, 6065-6078. [CrossRef]

8. Cerda-Garcia-Rojas, C.M.; Hernandez-Vidal, H.H.; Joseph-Nathan, P. ${ }^{13}$ C-NMR assignments of D:C-friedours-7-ene derivatives. Evidence of an abnormal methyl group chemical shift. Magn. Reson. Chem. 1996, 34, 777-781. [CrossRef]

9. Fukuoka, M.; Natori, S. Oxidation of bauerenol derivatives with chromium trioxide. Confirmation of the structure of bauerenol. Chem. Pharm. Bull. 1972, 20, 974-979. [CrossRef]

10. Hsu, C.-L.; Fang, S.-C.; Huang, H.-W.; Yen, G.-C. Anti-inflammatory effects of triterpenes and steroid compounds isolated from the stem bark of Hiptage benghalensis. J. Funct. Foods 2015, 12, 420-427. [CrossRef]

11. Pettit, G.R.; Numata, A.; Iwamoto, C.; Morito, H.; Yamada, T.; Goswami, A.; Clewlow, P.J.; Cragg, G.M.; Schmidt, J.M. Antineoplastic agents. 489. Isolation and structures of meliastatins 1-5 and related euphane triterpenes from the tree Melia dubia. J. Nat. Prod. 2002, 65, 1886-1891. [CrossRef] [PubMed]

12. Zare, S.; Ghaedi, M.; Miri, R.; Heiling, S.; Asadollahi, M.; Baldwin, I.T.; Jassbi, A.R. Phytochemical investigation on Euphorbia macrostegia (Persian wood spurge). Iran. J. Pharm. Res. 2015, 14, 243-249. [PubMed]

13. Wang, L.-Y.; Wang, N.-L.; Yao, X.-S.; Miyata, S.; Kitanaka, S. Euphane and tirucallane triterpenes from the roots of Euphorbia kansui and their in vitro effects on the cell division of xenopus. J. Nat. Prod. 2003, 66, 630-633. [CrossRef] [PubMed]

14. Abe, I.; Sakano, Y.; Tanaka, H.; Lou, W.; Noguchi, H.; Shibuya, M.; Ebizuka, Y. Enzymatic cyclization of 22,23-dihydro-2,3-oxidosqualene into euph-7-en-3 $\beta$-ol and bacchar-12-en-3 $\beta$-ol by recombinant $\beta$-amyrin synthase. J. Am. Chem. Soc. 2004, 126, 3426-3427. [CrossRef] [PubMed]

15. Zhang, Y.; Liu, C.; Dong, B.; Ma, X.; Hou, L.; Cao, X.; Wang, C. Anti-inflammatory activity and mechanism of surfactin in lipopolysaccharide-activated macrophages. Inflammation 2015, 38, 756-764. [CrossRef] [PubMed]

16. Kolhe, J.N.; Bhaskar, A.; Bringi, N.V. Occurrence of 3-oxo triterpenes in the unsaponifiable matter of some vegetable fats. Lipids 1982, 17, 166-168. [CrossRef]

17. Warashina, T.; Umehara, K.; Miyase, T. Constituents from the roots of Taraxacum platycarpum and their effect on proliferation of human skin fibroblasts. Chem. Pharm. Bull. 2012, 60, 205-212. [CrossRef] [PubMed]

18. Rojo de Almeida, M.T.; Rios-Luci, C.; Padron, J.M.; Palermo, J.A. Antiproliferative terpenoids and alkaloids from the roots of Maytenus vitis-idaea and Maytenus spinosa. Phytochemistry 2010, 71, 1741-1748. [CrossRef] [PubMed] 
19. Zhong, H.-T.; Li, F.; Chen, B.; Wang, M.-K. Euphane triterpenes from the bark of Broussonetia papyrifera. Helv. Chim. Acta 2011, 94, 2061-2065. [CrossRef]

20. Siddiqui, S.; Hafeez, F.; Begum, S.; Siddiqui, B.S. Oleanderol, a new pentacyclic triterpene from the leaves of Nerium oleander. J. Nat. Prod. 1988, 51, 229-233. [CrossRef]

21. Yamada, T.; Muroga, Y.; Jinno, M.; Kajimoto, T.; Usami, Y.; Numata, A.; Tanaka, R. New class azaphilone produced by a marine fish-derived Chaetomium globosum. The stereochemistry and biological activities. Bioorg. Med. Chem. 2011, 19, 4106-4113. [CrossRef] [PubMed]

22. Matsui, Y.; Kikuchi, T.; Inoue, T.; Muraoka, O.; Yamada, T.; Tanaka, R. Carapanolides J-L from the seeds of Carapa guianensis (andiroba) and their effects on LPS-activated NO production. Molecules 2014, 19, 17130-17140. [CrossRef] [PubMed]

Sample Availability: Samples of the compounds are not available.

(C) 2016 by the authors; licensee MDPI, Basel, Switzerland. This article is an open access article distributed under the terms and conditions of the Creative Commons Attribution (CC-BY) license (http://creativecommons.org/licenses/by/4.0/). 